\title{
APPLICATION OF THE CONSTITUTIONAL PRIVACY RIGHT TO EXCLUSIONS AND DISMISSALS FROM PUBLIC EIIPLOYMENT
}

The public employer has traditionally enjoyed considerable freedom to lire and fire on the basis of the "immorality" of an applicant or employee. Recently, this freedom has been eroded by two significant judicial developments: the expansion of the sphere of personal interests protected against government infringenent under the constitutional right to privacy, and the increased willingness of the courts to apply strict standards of substantive judicial review to public employment decisions, especially those decisions which penalize the exercise of a constitutional right.

These developments potentially affect a large segment of the American labor force. An estimated 14,000,000 persons are directly employed by federal, state, and local governments. ${ }^{1}$ An additional undetermined number work for employers under contract with the federal government and are thus often subject to security clearance requirements ${ }^{2}$ and governmental determinations of fitness. Moreover, workers in the nominally private sector may be deemed "public" employees if the private employer performs a sufficiently public function to be reached under the "state action" doctrine. ${ }^{3}$ Many other indi-

1. 96 MONThLY LAB. ReV., Aug., 1973, at 110.

2. See, e.g., Cafeteria Workers Local 473 v. McElroy, 367 U.S. 886 (1961); Greene v. McElroy, 360 U.S. 474 (1959); Adams v. Laird, 420 F.2d 230 (D.C. Cir.), cert. denied, 397 U.S. 1039 (1970); Gayer v. Laird, 332 F. Supp. 169 (D.D.C. 1971). For a description of the Industrial Security Clearance Review Office, the agency currently charged with screening security clearances issued to workers on federal government projects, and the manner in which the Review Office can operate to exclude persons for deviant behavior, see Note, Security Clearances for Homosexuals, 25 Stan. L. Rev. 403, 404-16 (1973).

3. Cf. Food Employees Local 590 v. Logan Valley Plaza, 391 U.S. 308 (1968) (shopping center to which public has virtually unrestricted access cannot, consistently with the first and fourteenth amendments, exclude peaceful picketing and handbilling directed against a shopping center employer); Marsh v. Alabama, 326 U.S. 501 (1946) (company-owned town freely used by general public cannot deny first amendment freedoms to a distributor of religious literature); Lavoie v. Bigwood, 457 F.2d 7 (1st Cir. 1972) (mobile home park tenant adequately alleged state action by asserting a municipal purpose to restrict mobile home sites and a concomitant private monopoly 
viduals must satisfy governmental licensing requirements before pursuing their chosen profession. ${ }^{4}$

Restraints placed upon these government-related employees traditionally arose from statutory and regulatory provisions authorizing the public employer to terminate or deny employment upon a finding of immoral behavior. ${ }^{5}$ Employers have zealously exercised this power in a variety of circumstances against numerous individuals: the postal clerk dismissed for "immoral conduct" when his superiors learned that he was living with a young unmarried woman; ${ }^{\circ}$ the schoolteacher whose allegedly offensive private letters were turned over to the local police, leading to a dismissal for "immorality"; ${ }^{7}$ the police candidate who was terminated when his supervisors discovered his membership in a nudist caunp; ${ }^{8}$ the secondary schoolteacher whose certification was revoked after his superiors' discovery of an isolated homosexual incident that had occurred several years earlier; ${ }^{9}$ the electronics engineer who worked for a private company under a defense contract and whose security clearance was suspended when he refused to answer detailed questions

over the allocation of these sites). But cf. Lloyd Corp. v. Tanner, 407 U.S. 551 (1972) (shopping center not required under first and fourteenth amendments to allow handbilling which is unrelated to any shopping center activity and for which adequate alternative means of communication are available).

4. Attorneys have frequently been subject to disbarment proceedings for constitutionally protected activity. See, e.g., Spevack v. Klein, 385 U.S. 511 (1967) (reversing disbarment imposed upon attorney who had asserted privilege against self-imcrimination); Konigsberg v. State Bar, 353 U.S. 252 (1957) (former membership in Communist Party, present criticism of public officials and policies, and refusal to answer questions about political matters do not justify denial of admission to bar); Schware v. Board of Bar Examiners, 353 U.S. 232 (1957) (former "subversive" associntions constitute insufficient evidence of moral unfitness to practice law).

5. See, e.g., ALA. CoDE tit. 52, \& 358 (1960) (public schooltenchers removable for "immorality"); CAL. Gov'T CODE § 19,572 (West 1963) (state civil service employees may be disciplined for "immorality" or "failure of good behavior . . . either during or outside of duty hours"); FLA. STAT. ANN. \& 231.28(6)(c) (West Supp. 1973) (teachers removable for "conduct involving any iminoral, unnatural, or lascivious act"); N.M. STAT. ANN. ch. 5, art. 3, \& 4 (1966) (local officers can be removed for "gross immorality"); PA. STAT. ANN. tit. 24, \& 12-1209 (1962) (teacher's certificate will not be issued to "person who has not a good moral character"); 5 C.F.R. $\S 731.201(b)$ (1973) (federal civil service employment can be terminated or denied for "[c]riminal, infamous, dishonest, immoral, or notoriously disgraceful conduct").

6. Mindel v. United States Civil Serv. Comm'n, 312 F. Supp. 485 (N.D. Cal. 1970). 1967).

7. Jarvella v. Board of Edua, 12 Ohio Misc. 288, 233 N.E.2d 143 (Ct. C.P.

8. Bruns v. Pomerleau, 319 F. Supp. 58 (D. Md. 1970).

9. Morrison v. State Bd. of Educ., 1 Cal. 2d 214, 461 P.2d 375, 82 Cal. Rptr. 175 (1969). 
about his sex life; ${ }^{10}$ and the matronly schoolteacher who allowed several of her son's friends to spend nights at her home and whose contract was therefore terminated for conduct "unbecoming a teacher."11

Each type of conduct penalized in the above examples falls arguably within "that ill-defined area of privacy which is increasingly if indistinctly recognized as a foundation of several specific constitutional protections."12 As employees grow increasingly bold in asserting their constitutional rights, the tensions between a public employer's hiring prerogatives and the individual employee's personal privacy will continue to seek a judicial outlet. This Note will examine (1) the constitutional safeguards available to the public employee in such cases, giving particular attention to the expansion of the right to privacy heralded by the recent United States Supreme Court decision in Roe v. Wade; ${ }^{13}$ (2) the recently heightened standards of substantive judicial review of public employment decisions; and (3) the nature of the procedural safeguards to which a public employee is entitled.

\section{Right to Privacy: The Expanding Zone of Protected InTERests}

That the Constitution protects certain fundamental rights not specifically found therein is by no means a new doctrine. ${ }^{14}$ Thus, when the United States Supreme Court first recognized privacy as a distinct constitutional right im Griswold v. Connecticut, ${ }^{15}$ it was not breaking entirely new ground. ${ }^{16}$ In Griswold the Court asserted that "[s]pecific

10. Gayer v. Laird, 332 F. Supp. 169 (D.D.C. 1971). The demands for information included the following inquiries: "Name or describe the sexual acts engaged in with other male(s)"; "Approximately how many such acts have occurred?"; "Where were such acts performed?"; and "What were the circumstances leading to the last such act? (Be specific as to where [and] when ... the act was performed)." Id. at 170 .

11. Fisher v. Snyder, 346 F. Supp. 396 (D. Neb. 1972).

12. Norton v. Macy, 417 F.2d 11 161, 1164 (D.C. Cir. 1969).

13. 410 U.S. 113 (1973).

14. The United States Supreme Court has applied this principle in a number of areas, most notoriously in the since discredited line of cases associated with Lochner v. New York, 198 U.S. 45 (1905), which extended constitutional due process to the liberty to work and to contract without excessive or unreasonable state interference. See, e.g., Adkins v. Children's Hospital, 261 U.S. 525 (1923); Coppage v. Kansas, 236 U.S. 1 (1915). The Court has more recently extended protection to "basic" rights not explicitly mentioned in the Constitution. See Greene v. McElroy, 360 U.S. 474 (1959) (right to follow chosen profession); Skinner v. Oklahoma, 316 U.S. 535 (1942) (right to have offspring).

15. 381 U.S. 479 (1965).

16. Anticipation of a constitutional right to privacy can be found in the language of earlier decisions. See, e.g., NAACP v. Alabama, 357 U.S. 449, 466 (1958) ("im- 
guarantees in the Bill of Rights have penumbras, formed by emanations from those guarantees that help give thein life and substance,"17 and that several guarantees, in particular the first, third, fourth, fifth, and ninth amendments, thus create a zone of personal privacy. ${ }^{18}$ The Court then found that marriage is a relationship within this zone of privacy $^{19}$ and that therefore the Connecticut statute challenged in the case for banning the use of contraceptives had involved a means of regulation which swept with unnecessary breadth into the zone of marital privacy. ${ }^{20}$ However, when coupled with Justice Goldberg's opinion that the Griswold holding "in no way interferes with a State's proper regulation of sexual promiscuity," 21 the Court's recognition that the statute dealt with activities constitutionally subject to state regulation ${ }^{22}$ may have indicated an intention to relegate the exact delineation of the right to privacy to future decisions. ${ }^{23}$

The courts after Griswold consequently experienced considerable difficulty in distinguishing between those activities which were constitutionally protected and those which were the objects of "a State's proper regulation." Although lower courts initially restricted the apphication of Griswold to the right of marital privacy, ${ }^{24}$ at least one de-

munity from state scrutiny of membership lists" was granted on ground that members had "the right ... to pursue their lawful interests privately"); Boyd v. United States, 116 U.S. 616,630 (1886) ("sanctity of a man's home and the privacies of life" protected by both the fourth and fifth amendments-suggestive of the "penumbra" analysis later employed in Griswold).

17. 381 U.S. at 484.

18. Id. at $484-85$.

19. Id. at 485 .

20. Id., citing NAACP v. Alabama, 377 U.S. 288, 307 (1964), which held that a "governmental purpose to control or prevent activities constitutionally subject to state regulation may not be achieved by means which sweep unnecessarily broadly and thereby invade the area of protected freedoms." See notes 73-74 infra and accompanying text.

21. Id. at 498-99 (concurring opinion).

22. 381 U.S. at 485.

23. Until 1972 the Court was generally silent as to whether the right might be extended to other than marital relationships. Although there are no explicit Supreme Court extensions of the right to privacy during this period, the case of Stanley v. Georgia, 394 U.S. 557 (1969) (statute prohibiting the private possession of obscene materials declared unconstitutional), which is couched primarily in first amendment terms, has recently been cited as illustrative of the constitutional right to privacy. See Paris Adult Theatre I v. Slaton, 93 S. Ct. 2628, 2639 (1973). The Stanley opinion briefly discusses the privacy "dimension" of the case. 394 U.S. at 564.

24. See, e.g., Cotner v. Henry, 394 F.2d 873, 875 (7th Cir.), cert. denied, 393 U.S. 847 (1968) (holding Griswold applicable to "private, consensual, marital relations"). See also Buchanan v. Batchelor, 308 F. Supp. 729 (N.D. Tex. 1970), vacated and remanded on other grounds sub nom. Wade v. Buchanan, 401 U.S. 989 (1971), where the plaintiffs seeking an injunction and declaratory relief included a 
cision recognized a constitutional right to privacy in extramarital heterosexual relations; $; 5$ and a few courts made rather equivocal suggestions that the right to privacy might extend to homosexual relations as well. ${ }^{26}$ In addition, several cases granted protection to private matters not involving a sexual relationship. ${ }^{27}$ These varying interpretations of Gris-

publicly confessed homosexual, a homosexual fearing future prosecution for private acts, and a married couple alleging fears of prosecution for sodomy within the marital relationship. The three-judge district court in Buchanan held the statute void on its face for unconstitutional overbreadth because it reached private, consensual marital acts.

25. Mindel v. United States Civil Serv. Comm'n, 312 F. Supp. 485 (N.D. Cal. 1970) (invalidating dismissal of postal clerk for living with young unmarried woman).

26. In Morrison v. State Bd. of Educ., 1 Cal. 3d 214, 461 P.2d 375, 82 Cal. Rptr. 175 (1969), the Supreme Court of California invalidated the dismissal of a schoolteacher for an isolated past homosexual act. The Morrison court was concerned not with whether homosexual relations as such should be accorded constitutional protection, but rather with the intrusions into teachers' private lives which a flat statutory ban on "immoral conduct" might encourage. Id. at 233-34, 461 P.2d at 390, $82 \mathrm{Cal}$. Rptr. at 190. In McConnell v. Anderson, 451 F.2d 193 (8th Cir. 1971), cert. denied, 405 U.S. 1046 (1972), the court of appeals upheld the state university's rejection of plaintiff's application for a position in the campus library. Noting that plaintiff liad publicly advocated homosexuality, the court suggested that his conduct might have been protected if he had had "mere homosexual propensities" or "a desire clandestinely to pursue homosexual conduct." 451 F.2d at 196. In Norton v. Macy, 417 F.2d 1161 (D.C. Cir. 1969), a homosexual had been dismissed from the federal service. The case was decided on the basis of statutory and due process considerations, but there is dictum to the effect that the right to privacy might be extended to private homosexual acts: "The Due Process Clause may also cut deeper into the Government's discretion where a dismissal involves an intrusion upon that ill-defined area of privacy which is increasingly if indistinctly recognized as a foundation of several specific constitutional protections." Id. at 1164. "[T] $]$ he notion that it could be an appropriate function of the federal bureaucracy to enforce the majority's conventional codes of conduct in the private hives of its employees is at war with elementary concepts of liberty, privacy, and diversity." Id. at 1165 . In re Labady, 326 F. Supp. 924 (S.D.N.Y. 1971), held that a homosexual whose conduct was private and did not affect his ability to be a law-abiding and useful citizen could not be denied naturalization. The case was decided on statutory grounds, but again the court in dictum asserted: "To the extent that these laws seek to prohibit and punish private homosexual behavior between consenting adults, they are probably unconstitutional." Id. at 929 n.4.

27. See, e.g., Stanley v. Georgia, 394 U.S. 557 (1969) (possession of obscene naterials was given constitutional protection); Fisher v. Snyder, 346 F. Supp. 396 (D. Neb. 1972) (termination of schoolteacher's contract was not justified by the fact that she permitted friends of her son to sleep at her home under circumstances which provided "no permissible inference of immorality"); City of Carmel-By-The-Sea v. Young, 2 Cal. 3d 259, 466 P.2d 225, 85 Cal. Rptr. 1 (1970) (right to privacy as well as fourth amendment prohibited compulsory disclosure, from every public officer and candidate, of nature and extent of investments owned by self, spouse, and minor children); Jarvella v. Board of Educ., 12 Ohio Misc. 288, 233 N.E.2d 143 (Ct. C.P. 1969) (private letters alone could not support discharge of public schoolteacher). 
wold dramatically underscored the need for a uniform constitutional standard.

The 1972 case of Eisenstadt v. Baird ${ }^{28}$ presented the Supreme Court with an ideal opportunity for extending the protection of Griswold to married and unmarried persons alike. Baird had been convicted under a Massachusetts statute for distributing contraceptive foam to a young woman student at the close of a university lecture. While holding that Baird did have standing to raise the rights of unmarried persons affected by the statute, ${ }^{29}$ the Supreine Court did not simply declare the statute unconstitutional as a ban on contraception per se and a violation of fundamental rights protected under Griswold. ${ }^{30}$ Instead, by applying a strict standard of rationality to the state's attempted justifications, the Court found the statute objectionable on equal protection grounds. ${ }^{31}$ It was only by way of dictum that the Court imdicated its willingness to extend the application of Griswold to unmarried persons:

The marital couple is not an independent entity with a heart and mind of its own but an association of two individuals each with a separate intellectual and emotional makeup. If the right of privacy means anything, it is the right of the individual, married or single, to be free froin unwarranted governmental intrusion into matters so fundamentally affecting a person as the decision whether to bear or beget a child. ${ }^{32}$

Roe v. Wade $e^{33}$ has since elevated this dictum to a constitutional mandate. In Wade a pregnant unmarried woman challenged the constitutionality of the Texas criminal abortion statutes, which permitted abortions only to save the inother's life. The Supreme Court held that the right to privacy, though extending only to "fundamental" rights

28. 405 U.S. 438 (1972).

29. Id. at 446. The standing decision was based primarily upon the fact that, as the Massachusetts statute banned the distribution rather than the use of contraceptives, uninarried persons claiming a right to use contraceptives had no forum in which they could effectively assert their interests. This jus tertii was derived by analogy from first amendinent cases applying the same principle. See, e.g., NAACP v. Alabama, 357 U.S. 449 (1958).

30. This conclusion had been reached in the same case by the Court of Appeals for the First Circuit. See Baird v. Eisenstadt, 429 F.2d 1398, 1402 (1st Cir. 1970).

31. For a discussion of the "new" equal protection standard, which mandates a serious "rationality" review of classifications not inherently "suspect," see Gunther, The Supreme Court, 1971 Term-Foreword: In Search of Evolving Doctrine on a Changing Court: A Model for a Newer Equal Protection, 86 HARv. L. Rev. 1, 17-24 (1972).

32. 405 U.S. at 453.

33. 410 U.S. 113 (1973). 
and rights "implicit in the concept of ordered liberty,"34 is broad enough to encompass a woman's decision to terminate an unwanted pregnancy. ${ }^{35}$ The Court then, for the first time, expressly lield that infringements upon the right to privacy must be justified by a "coinpelling state interest."36 Recognizing the state's legitimate interest in preserving life, the Court identified that moment when the fetus becoines capable of meaningful life apart from the mother's womb as the point at which the state's interest in preserving life becomes compellimg. ${ }^{37}$ At the instant the fetus becomes "viable," a state can proscribe abortion, except when termination of the pregnancy is necessary to safeguard the mother's life or health. Before this poimt, the mother's protected right to privacy must be considered the dominant interest. $^{38}$ The Court supported this new extension of the right to privacy with a mere recital of the hardships caused by abortion laws, ${ }^{30}$

34. Id. at 152. This principle was reaffinned later in the term. See Paris Adult Theatre I v. Slaton, 93 S. Ct. 2628, 2639 (1973).

35. 410 U.S. at 153.

36. Id. at 155 . The California Supreme Court had already expressly extended this requirement to state infringements of the right to privacy in City of Carmel-By-TheSea v. Young, 2 Cal. 3d 259, 466 P.2d 225, 85 Cal. Rptr. 1 (1970). The "compelling state interest" test is most often applied in equal protection cases involving suspect classifications or infringements upon fundamental rights. See, e.g., Kramer v. Union Free School Dist., 395 U.S. 621, 627-28 (1969); Shapiro v. Thompson, 394 U.S. 618, 634 (1969). However, the test has also been applied to an infringement upon the first amendment guaranty of free exercise of religion. Sherbert v. Verner, 374 U.S. 398,406 (1963). Since a compelling state interest was necessary to validate infringements of these other fundamental rights protected by the fourteenth amendment, the extension of this requirement to the fundamental right of privacy slould not have been surprising.

37. 410 U.S. at 163.

38. A companion case, Doe v. Bolton, 410 U.S. 179 (1973), extended the same protection to a married woman who, under Georgia law, had been denied an abortion after eight weeks of pregnancy.

39. The Wade court emphasized:

Specific and direct harm medically diagnosable even in early pregnancy may be involved. Maternity, or additional offspring, may force upon the woman a distressful life and future. Psycliological harm may be imminent. Mental and plysical health may be taxed by child care. There is also the distress, for all concerned, associated with the unwanted child, and there is the problem of bringing a cliild into a family already unable, psychologically or otherwise, to care for it. In other cases, as in this one, the additional difficulties and continuing stigma of unwed motherlood may be involved. 410 U.S. at 153.

For criticisms of Wade, see Ely, The Wages of Crying Wolf: A Comment on Roe v. Wade, 82 YAle L.J. 920 (1973); Miller, Privacy in the Corporate State: A Constitutional Value of Dwindling Significance, 22 J. PUB. L. 3, 19-22 (1973). Professor Ely argues that Griswold and its pre-Wade progeny were alike in that enforcement of the challenged laws would have required "the most outrageous sort of governmental prying into the privacy of the home," Ely, supra at 930 , but that Wade departed from this principle. Id. at 932. That Griswold was concerned primarily with intrusions into the home is slown by the fact that its holding invalidated only that 
thereby seeming to indicate that considerations of wise social policy alone might justify protection of certain types of alleged "immoral" conduct.

In Paris Adult Theatre I v. Slaton, ${ }^{40}$ the Court attempted to define further the scope of the riglit to privacy. In defending a civil suit to enjoin the slowing of two allegedly obscene films, the theatre's owners and managers had contended, inter alia, that sucls an injunction would violate the prospective viewers' constitutionally protected right to privacy. The Court's rejection of this argument provides a most imstructive insight into the categories of interests protected by the right to privacy: "This privacy right encompasses and protects the personal intimacies of the hoine, the family, marriage, motherhood, procreation, and child rearing." ${ }^{11}$ To reconcile Paris Adult Theatre with Stanley v. Georgia, which invalidated a state law penalizing the private possession of obscene materials, ${ }^{42}$ the Court expressly limited Stanley to the privacy of the home and declined to "equate the privacy of the hoine relied on in Stanley with a 'zone' of 'privacy' that follows a distributor or a consumer of obscene materials wherever lie goes." ${ }^{43}$

The protection afforded by Stanley $v$. Georgia . . . is restricted to a place, the home. In contrast, the constitutionally protected privacy of family, marriage, motherhood, procreation, and child rearing is not just concerned with a particular place, but with a protected imtimate relationship. Such protected privacy extends to the doctor's office, the hospital, the hotel room, or as otherwise required to safeguard the right to intimacy involved. ${ }^{44}$

Thus, the riglit of privacy lias sprouted at least two branclies: a broad protection of the home from governmental intrusion and a safeguarding of certain "intimate relationships" when confined to appro-

pcrtion of the state statute "that permitted the police to search the sacred precincts of marital bedrooms for telltale signs of the use of contraceptives." 381 U.S. at 485-86. Professor Ely complains that the expansion of the right to privacy in Wade "is not inferable from the language of the Constitution, the framers' thinking respecting the specific problem in issue, any general value derivable from the propositions they included, or the nation's governmental structure." Ely, supra at 935-36. It should be noted that three of the five amendments relied upon in Griswold (the third, fourth, and fifth) are specific limitations upon the governinent's power to pry and intrude; and a "penumbra" inferred from these amendments concerning the right to be free from excessive governmental prying or intrusion is still rather securely linked to the language of the Bill of Rights, in contrast to the publia policy value judgments which are the liallmark of Wade.

40. 93 S. Ct. 2628 (1973).

41. Id. at 2639.

42. See note 23 supra.

43. Paris Adult Theatre I v. Slaton, 93 S. Ct. 2628, 2640 (1973).

44. Id. at 2640 n.13. 
priate locations closely associated with the very nature of the relationship. The latter branch as outlined in Paris Adult Theatre seemingly parallels the "reasonable expectation of privacy" protection provided by the fourth amendment: ${ }^{45}$ "Obviously, there is no necessary or legitimate expectation of privacy which would extend to marital intercourse on a street corner or a theatre stage." ${ }^{46}$ Despite this caveat as to the appropriate places for the pursuit of private interests, the extensive protection afforded an individual within "the hoine" would seem to promise unlimited protection to private consensual relations. However, the Supreme Court has not only explicitly repudiated the contention that "one has an unlimited right to do with one's body as one pleases," cannot constitutionally regulate private conduct involving consenting adults. ${ }^{48}$

Wade and Paris Adult Theatre exemplify the Supreme Court's failure to articulate clear guidelmes that would dispel the confusion created by Griswold. As a result of this failure, conscientious judges must still grapple with such questions as whether certain private conduct represents a right imphicit in the concept of ordered liberty ${ }^{49}$ or whether given acts, although performed solely within the privacy of the home, are nevertheless in that category of conduct which the state is entitled to regulate. The danger-and, in view of the lack of clear standards, the necessity-of judicial "value sculpting"50 is evident. Wade itself, with its exclusive rehance upon policy arguments in expanding the right to privacy, was a value-sculpting exercise. Moreover, Wade's requirement that restrictions of the right to privacy represent a "compelling

45. See, e.g., Katz v. United States, 389 U.S. 347 (1967) (government electronic surveillance of petitioner's telephone booth conversations without prior warrant violated the privacy upon which petitioner justifiably relied and thus constituted an illegal search and seizure within meaning of fourth amendment).

46. Paris Adult Theatre I v. Slaton, 93 S. Ct. 2628, 2640 n.13 (1973).

47. Roe v. Wade, 410 U.S. 113, 154 (1973).

48. Paris Adult Theatre I v. Slaton, 93 S. Ct. 2628, 2641 (1973). In so doing the Court referred to the numerous "constitutionally unchallenged laws" regulating the conduct of consenting adults. Id. at $2641 \mathrm{n} .15$. The examples cited include mutual combat, suicide, and self-mutilation, demonstrating that the Court was perhaps giving the rejected contention a broader meaning not intended by its proponents. In its more restricted sense covering voluntary sexual relations, the argument for a "right to do with one's body as one pleases" has often been urged by commentators. See, e.g., Comment, The Bedroom Should Not Be Within the Province of the Law, 4 CAL. IV.L. Rev. 115 (1968); Comment, Regulation of Sexual Conduct by Withholding Govermment Benefits and Privileges, 3 U.S.F.L. Rev. 372, 387 (1969); Note, 49 Tex.ss

L. REV. 400, 405 (1971).

49. See text accompanying note 34 supra.

50. See note 39 supra and accompanying text. 
state interest" further invites decision by judicial value judgment, in that judges in other areas of the law have enjoyed wide latitude in designating state interests as "compelling." "61

This expansive judicial discretion is graphically illustrated by the recent post-Wade case of Acanfora $v$. Board of Education, ${ }^{\text {t2 }}$ involving the involuntary transfer and eventual dismissal of a homosexual schoolteacher. In Acanfora private consenting homosexuahty is for the first time explicitly included within the zone of interests protected by the constitutional right to privacy. In the wake of Wade, it should perhaps not be surprising that the district court in Acanfora based the creation of a constitutionally protected interest upon pure policy arguments, placing more emphasis on the theories of John Stuart Mill than on well established principles of law. ${ }^{53}$ The court justified its excur-

51. See, e.g., Sherbert v. Verner, 374 U.S. 398 (1963) (invalidating the disqualification for unemployment benefits of a Seventh-Day Adventist whose inability to find work was due to her religious refusal to work on Saturdays). In considering an earlier case similarly mvolving an economic penalty for religious beliefs, Sherbert distinguished Braunfeld v. Brown, 366 U.S. 599 (1961) (upholding application of Sunday closing laws to Jewislı merchants who for religious reasons remained closed on Saturdays) on the ground that a secular state interest in providing a uniform day of rest was compelling. 374 U.S. at 408 . In contrast, strict scrutiny was applied to the state claims of possible welfare fraud in Sherbert itself. Id. at 406-09.

52. 359 F. Supp. 843 (D. Md. 1973), concerning the transfer and ultimate failure to renew the contract of a homosexual teacher at a junior ligh school. The court lield that homosexuality was protected by the constitutional right to privacy and applied strict scrutiny to the school board's justifications. Acanfora declared the board's policy of not employing homosexuals at all unconstitutional but upheld the refusal to reinstate the teacher or renew his contract on the basis of the extensive media publicity which the teacher had sought and gained since his transfer. The court based its decision on its finding that this publicity had a deleterious effect upon the educational process and that the speech leading to the publicity was not "protectable" speech. See notes 83-87 infra and accompanying text.

53. The flavor of the opinion can best be indicated by the language of the court:

As autonomous and rational beings, individuals are capable of reasoned decisions in pursuit of chosen goals. Given man's imperfect knowledge, full freedom of thought and association is imperative for individual development and social progress. So long as the freedoms of others are not affected, a government intended to promote the life, liberty and happiness of its citizens must abstain from interference with individual pursuits, no matter how unorthodox or repulsive to the majority. As social animals, individuals necessarily place importance on friendships and relationships of trust. Hence the development of a right of privacy. . . .

In this context, the time has come today for private, consenting, adult homosexuality to enter the sphere of constitutionally protectable interests. Intolerance of the unconventional halts the growth of liberty. . . .

It is no less true now than when written in 1859 that although society no longer puts heretics and sinners to death, nor does it act so vigorously as to stamp them out, it cannot flatter itself as free from the stain of legal persecution. The chief harm in these laws is the perpetuation of socinl stigma, cramping inental development, cowing reason, and repressing human expression for fear of social disfavor. Id. at 850-52. 
sion into the field of public policy with the declaration that "in inatters touching personal liberty, the Fourteenth Amendment expresses an integral philosophy of liberal democracy, not simply an amalgam of differentiated clauses [i.e., the Bill of Rights]." ${ }^{.54}$

\section{Expanded Judicial Review of the Public Employer's DECISION TO HIRE AND FIRE}

The protection of inore activities and relationships under the expanded right to privacy offers little solace to the dismissed employee unless he is also able to command a serious review of the employment decision. In examining a government employer's decision to dismiss an einployee or reject an applicant, the courts have traditionally offered three principal justifications for applying a judicial review standard of minimal scrutiny. First, great deference has been paid to administrative determinations of employee coinpetence, particularly in the review of dismissals from federal employment, where the doctrine of separation of powers is arguably applicable. ${ }^{55}$ The inost which a dismissed federal employee could demand was coinpliance with applicable statutory procedures; a few recent decisions have continued to limit review to this inquiry. ${ }^{56}$ Second, a lower standard of review las previously been applied when the challenged public employment decision concerns the government's "proprietary" function as a direct employer than when a "regulatory" decision such as the issuance or denial of professional credentials lias been questioned. ${ }^{57}$ Third, minimal judi-

An interesting feature of the Acanfora opinion is its explicit recognition of the Griswold-Wade line of decisions along with the discredited cases associated with Lochner v. New York, 198 U.S. 45 (1905). See note 14 supra. The two series of cases are cited together as standing for the proposition that "the guarantee of liberty in the Fourteenth Amendment is greater than the sum of particular rights guaranteed in the first eight amendinents." 359 F. Supp. at 850.

54. 359 F. Supp. at 850.

55. See, e.g., Burnap v. United States, 252 U.S. 512, 515 (1920); Decatur v. Paulding, 39 U.S. (14 Pet.) 496, 515 (1840); Bailey v. Richardson, 182 F.2d 46, 56 (D.C. Cir. 1950); aff'd by an equally divided court, 341 U.S. 918 (1951).

56. See, e.g., Anonymous v. Macy, 398 F.2d 317 (5th Cir. 1968), cert. denied, 393 U.S. 1041 (1969); Hargett v. Summerfield, 243 F.2d 29 (D.C. Cir.), cert. denied, 353 U.S. 970 (1957).

57. See Comment, Due Process and Public Employment in Perspective: Arbitrary Dismissals of Non-Civil Service Employees, 19 U.C.L.A.L. Rev. 1052, 1068-74 (1972) (citing cases). For a criticism of this doctrine, see Van Alstyne, The Constitutional Rights of Public Employees: A Comment on the Inappropriate Uses of an Old Analogy, 16 U.C.L.A.L. Rev. 751, 752 (1969): "The fourteenth amendment . . . leaves no quarter for a ... view that this amendment shall not apply when the state acts in a proprietary, rather than in a governmental icapacity." "That the doctrine dies hard, however, is shown by Cafeteria Workers Local 473 v. McElroy; 367 U.S. 886, 
cial review has formerly been justified by the theory that public employment is not a "right" but rather a "privilege" that can be withdrawn even if the exercise of constitutional rights is thereby penalized. ${ }^{68}$

These various doctrines found classic expression in the 1950 case of Bailey v. Richardson, ${ }^{59} \mathrm{im}$ which the Court of Appeals for the District of Columbia Circuit upheld the dismissal of a civil service employee for alleged communist activities, which she stoutly denied but which she was unable to disprove because of the Government's refusal to reveal its anonymous informants:

[T]he ability, integrity and loyalty of purely executive employees is exclusively for the executive branch of Government to determine, except in so far as the Congress has a constitutional voice in the matter. All such employees hold office at the pleasure of the appointing authority . . . except only for statutory limitations. . . . 60

....

.. . The fundamental concept of the division of powers, and so of responsibilities, does not, in our opinion, permit the conclusion that the President cannot remove an employee in the executive branch without referring the matter to the judicial branch. . . . ${ }^{61}$

-...

... No function is more completely internal to a branch of government than the selection and retention or dismissal of its employees. ... ${ }^{62}$

896 (1961), where the Court, in upholding the summary revocation of the security clearance of a cook in a civilian concession at a military installation, said:

[T] he governmental function operating here was not the power to regulate or license, as lawmaker, an entire trade or profession, or to control an entire branch of private business, but, rather, as proprietor, to manage the imternal operation of an important federal miktary establishment. .... In that proprietary military capacity, the Federal Government, as has been pointed out, has traditionally exercised unfettered control.

58. The locus classicus is in McAuliffe v. Mayor of New Bedford, 155 Mass. 216, 29 N.E. 517 (1892), where a policeman who had been discharged souglit a writ of mandamus to restore him to his position. The officer had violated police regulations prohibiting membership in a political committee and the solicitation of money for political purposes. Judge (later Supreine Court Justice) Holmes remarked: "The petitioner may have a constitutional right to talk politics, but he has no constitutional light to be a policeman." Id. at 220,29 N.E. at 517. For a discussion of the extensive subsequent history of the McAuliffe principle, see Van Alstyne, The Demise of the Right-Privilege Distinction in Constitutional Law, 81 Harv. L. REv. 1439 (1968).

59. 182 F.2d 46 (D.C. Cir. 1950), aff'd by equally divided court, 341 U.S. 918 (1951).

60. 182 F.2d at 51 .

61. Id. at 56. For other cases applying this principle, see note 55 supra.

62. Id. at 58 . 
... No one denies Miss Bailey the right to any political activity or affiliation she may choose. What is denied ler is Government employ. ... . .

$\cdots$

... [I]f the Government, in the exercise of a governmental power, injures an individual, that individual lias no redress. ${ }^{64}$

With the steady erosion of these justifications, the discrediting of the right-privilege distinction, ${ }^{65}$ and the increasing judicial willingness to find substantive content in the often vague statutory language governing employee dismissals, ${ }^{66}$ a heightened due process standard of review has become the majority rule in the recent decisions. ${ }^{67}$ This revitalized substantive due process requirement demands (1) that a dismissal or failure to employ not be discriminatory, ${ }^{68}$ arbitrary, or capricious; ${ }^{60}$ (2) that it be based upon substantial evidence; ${ }^{70}$ and (3) that the grounds for the decision bear some reasonable relationship to the nature of the employment. ${ }^{71}$

63. Id. at 61. Earlier the court had said: "The First Ameudment guarantees free speech and assembly, but it does not guarantee Government employ." Id. at 59. These two statements are of course strikingly similar in phraseology to Justice Holmes' classic formulation of the principle. See note 58 supra.

64. Id. at 63. The plaintiff seems to have made the type of "hardship" argument which was later to win some favor with the courts: "But it is said that the public does not distinguish, that she has been stigmatized and her chance of making a living seriously impaired." Id. at 63. See notes 101-02, 107-08 infra and accompanying text.

65. See, e.g., Graham v. Richardson, 403 U.S. 365, 374 (1971): The Supreme Court "has now rejected the concept that constitutional rights turn upon whether a governmental benefit is characterized as a 'right' or as a 'privilege." "Wieman v. Updegraff, 344 U.S. 183, 192 (1952); see Van Alstyne, supra note 58.

66. Cases cited note 71 infra.

67. For discussions of the emergence of the heightened due process standard, see Comment, supra note 57; 58 GEo. L.J. 632 (1970).

68. See, e.g., Cafeteria Workers Local 473 v. McElroy, 367 U.S. 886, 898 (1961); Wieman v. Updegraff, 344 U.S. 183, 192 (1952).

69. See, e.g., McConnell v. Anderson, 451 F. 2d 193, 196 (8th Cir. 1971), cert. denied, 405 U.S. 1046 (1972); Dew v. Halaby, 317 F.2d 582, 585 (D.C. Cir. 1963). For a related legislative enactment, see Administrative Procedure Act $\S 2(\mathrm{a}), 10,5$ U.S.C. $\$ \$ 701-06$ (1970), which provides for judicial review of final agency actions except when precluded by statute or when agency action is committed to agency discretion by law. Section $706(2)$ (A) authorizes the reviewing court to set aside agency action if arbitrary or capricious.

70. See, e.g., Schlegel v. United States, 189 Ct. Cl. 30, 36, 416 F.2d 1372, 1375 (1969), cert. denied, 397 U.S. 1039 (1970). For the same standard, see Administrative Procedure Act $\$ 10(\mathrm{e}), 5$ U.S.C. $\$ 706(2)$ (E) (1970), which authorizes a reviewing court to set aside agency action found not to be supported by substantial evidence.

71. This standard is often applied by way of statutory interpretation. In Norton v. Macy, 417 F.2d 1161 (D.C. Cir. 1969), a NASA employee had been dismissed for making a homosexual advance away from the job. The court held that the apph- 
This stricter due process review has numerous ramifications for a public employee dismissed for "immoral" private activity. The dismissed employee will have a good chance of prevailing in court even if the court declines to include the specific conduct within the zone of constitutionally protected interests. ${ }^{72}$ In many cases, the "immorality" leading to dismissal will arguably have no bearing whatever upon an employee's job performance. When the bases for dismissal or selection are such that the exercise of a constitutionally protected activity is penalized, the employee can avail himself of the more stringent tests which have been developed to deal with infringements upon constitutional rights. It is clear that legitimate regulation of employee fitness and competence "cannot be pursued by means that broadly stifle fundamental personal liberties when the end can be more narrowly achieved."73 This standard requires that the einployer regulate private employee conduct by the least restrictive available means. ${ }^{74}$ In addition, any such regulation or employer action that impinges upon an individual's zone of protected privacy will now be strictly scrutinized in order to determine whether the infringement is necessary for the accomplishment of a legitimate state purpose. ${ }^{75}$ After Wade, not only

cable statute, 5 U.S.C. $\$ 863$ (1964), as amended, 5 U.S.C. $\$ 7512$ (a) (1970), which authorized agencies to remove "preference eligible" civil servants "only for such cause as will promote the efficiency of the service," required a showing of a specific connection between the employee's conduct and the efficiency of the service. Sce also Morrison v. State Bd. of Educ., 1 Cal. 3d 214, 461 P.2d 375, 82 Cal. Rptr. 175 (1969), where the court interpreted the relevant statute, CAL. EDUC. CoDE $\$ 13202$ (1959) (authorizing revocation of teaching certifications for "immoral conduct," "unprofessional conduct," or "acts involving moral turpitude") as specifying only such action as indicates an unfitness to teach. For application of this principle to bar admission requirements, see Law Students Civil Rights Research Council, Inc. v. Wadmond, 401 U.S. 154 (1971); Schware v. Bd. of Bar Examiners, 353 U.S. 232 (1957).

72. But see Comment, supra note 57, at 1052-53, 1056-58.

73. Shelton v. Tucker, 364 U.S. 479, 488 (1960). For other apphications of this principle to exclusions from public employment, see Keyishian v. Board of Regents, 385 U.S. 589, 602 (1967); Wieman v. Updegraff, 344 U.S. 183, 191 (1952). The principle is often applied when the state uses the criminal law to penalize directly the exercise of a constitutional right. See, e.g., Roe v. Wade, 410 U.S. 113, 155 (1973) (right of privacy); Griswold v. Connecticut, 381 U.S. 479, 485 (1965) (right of privacy); NAACP v. Alabama, 377 U.S. 288, 307 (1964) (freedom of association); Cantwell v. Connecticut, 310 U.S. 296, 307-08 (1940) (freedom of religion and speech).

74. See Bruff, Unconstitutional Conditions upon Public Employment: New Departures in the Protection of First Amendment Rights, 21 HAST. L.J. 129, 170-73 (1969); O'Neil, The Private Lives of Public Employees, 51 ORE. L. REv. 70, 110-11 (1971); cf. Dean Milk Co. v. City of Madison, 340 U.S. 349 (1951) (city's legitimate regulation of milk quality cannot employ means which burden interstate commerce if reasonable and adeqnate alternative methods of achieving the same purpose with less of a burden upon interstate commerce are available).

75. See San Antomio Independent School Dist. v. Rodriguez, 411 U.S. 1, 37-38 
must the privacy infrimgement be essential to the achievement of a legitimate state purpose, but that purpose must also represent a compelling state interest. ${ }^{76}$

Another facet of this heightened protection is the established principle that public employees cannot be compelled as a condition of their employment to relinquish the constitutional rights enjoyed by ordinary citizens. ${ }^{77}$ However, the question then becomes whether this employee right is absolute, or whether a substantial enougli state interest can outweigh the competing private imterests. The Supreme Court has employed both standards. Elfbrandt v. Russell ${ }^{8}$ and Keyishian v. Board of Regents, ${ }^{79}$ both of which invalidated state loyalty oath schemes for public schoolteachers, adopted the absolutist approacli by categorically rejecting the premise that "public employment . . . may be conditioned upon the surrender of constitutional rights which could not be abridged by direct government action."80 Only if an employee or applicant had actually violated the criminal law, which can constitutionally penalize only those political associations involving "active" membership in a subversive organization, ${ }^{81}$ could the public employer deny employment. No attempt was made in either case to weigh any competing state $\mathrm{m}$ terest which might reasonably have required standards different from those of the criminal law.

(1973); Skinner v. Oklahoma, 316 U.S. 535, 541 (1942). These cases stand for the proposition that "strict scrutiny" will be applied when state action imfringes a "fundamental" right. Since privacy can comprehend only those rights deemed "fundamental," Roe v. Wade, 410 U.S. 113, 152 (1973), the application of this principle to privacy cases is evident.

76. Roe v. Wade, 410 U.S. 113, 155 (1973). See note 36 supra.

77. See, e.g., Pickering v. Board of Educ., 391 U.S. 563, 568 (1968); Keyishian v. Board of Regents, 385 U.S. 589, 605 (1967); Johnson v. Branch, 364 F.2d 177, 180 (4th Cir. 1966), cert. denied, 385 U.S. 1003 (1967); cf. Sherbert v. Verner, 374 U.S. 398, 404 (1963) (holding invalid a state scheme under which a Seventh Day Adventist who refused to work on Saturdays was denied unemployment benefits); Speiser v. Randall, 357 U.S. 513, 518 (1958) (invalidating loyalty oath as prerequisite to qualification for veterans' tax exemption); Dixon v. Alabama, 294 F.2d 150 (5th Cir.), cert. denied, 368 U.S. 930 (1961) (state cannot condition privilege of university education upon renunciation of constitutional right to procedural due process). For discussions of the history of the "unconstitutional conditions" doctrine froin its imception in decisions limiting the state's regulation of nonresident corporations to the present emphasis upon governmental benefits, see O'Neil, Mr. Justice Brennan and the Condition of Unconstitutional Conditions, 4 RUTGRRS-CAMDEN L.J. 58 (1972); Comment, Another Look at Unconstitutional Condtions, 117 U. PA. L. Rev. 144 (1968).

78. 384 U.S. 11 (1966).

79. 385 U.S. 589 (1967).

80. Id. at 605 .

81. See, e.g., Noto v. Umited States, 367 U.S. 290 (1961); Scales v. Umited States, 367 U.S. 203 (1961); Yates v. Umited States, 354 U.S. 298 (1957). 
Pickering v. Board of Education ${ }^{82}$ exemplifies the balancing test approach. In Pickering, a schoolteacher who had written a letter to a local newspaper criticizing the allocation of school funds was thereupon dismissed for conduct detrimental to the best interests of the educational system. The Court weighed the teacher's first amendment claims agamst the need for orderly school administration ${ }^{83}$ and concluded that the school administration's interest in restricting the teacher's freedoin of speech was not significantly greater than if he had been an ordinary citizen. $^{84}$ In striking the balance in favor of the teacher, the Court nevertheless indicated that the public employer could condition employment upon the surrender of constitutional rights which the employee would enjoy as a member of the general public. In these cases, the line of demarcation lias in effect been drawn where the activity causes a

82. 391 U.S. 563 (1968).

83. Id. at 569 .

84. Id. at 573. Pickering, like Keyishian, states that teachers may not constitutionally be compelled to relinquish the first annendment rights they would otherwise cnjoy as citizens. However, Pickering makes it clear that, if the instructor's exercise of his first amendment rights should cause such harm to the educational system that his interest in freedoin of speech is outweighed by the school board's interest in orderly school administration, his first amendment rights could be restricted to a level below that of the average citizen. A reading of the two cases shows that Pickering carefully weighs the state interests involved by considering the effects which the teacher's action might have upon the school system, id. at 569-73, whereas Keyishian does not attempt to weigh the harmful results which the teachers' action might have. The Court also applied the balancing test in United States Civil Serv. Comm'n v. National Ass'n of Ietter Carriers, 93 S. Ct. 2880 (1973), which reaffirmed United Pub. Workcrs v. Mitchell, 330 U.S. 75 (1947), in upholding the Hatch Act restrictions upon partisan political activity by federal employees, 5 U.S.C. $\$ 7324$ (a)(2) (1970). On the other hand, the Letter Carriers case balanced the competing interests rather carefully, in contrast to the due-process-reasonableness approach taken by United Pub. Workers. The rise of the "unconstitutional conditions" doctrine since United Pub. Workers had led to speculation that the case might be overruled. See, e.g., The Supreme Court, 1966 Term, 81 HaRv. L. Rev. 69, 170-71 (1967). Cf. Healy v. James, 408 U.S. 169,191 (1972) (college administration's fear of student violence is outweighed by students' first anendment rights so long as there is no substantial threat of material disruption and the adininistration's concern is little more than "undifferentiated fear or apprchension of disturbance"); Tinker v. Des Moines Independent Community School Dist., 393 U.S. 503 (1969) (students' freedom of symbolic speech is more important than school principals' interest in order, absent a showing that the conduct would materially and substantially interfere with the requirements of appropriate discipline in the operation of the schools). See also Slochower v. Board of Educ., 350 U.S. 551 (1956); Bagley v. Washington Township Hosp. Dist., 65 Cal. 2d 499, 421 P.2d 409, 55 Cal. Rptr. 401 (1966).

For a detailed history of the Court's vacillations on the issue of the appropriate test to be applied to exclusions from public cmployment, see Leahy, The Public Employee and the First Amendment-Must He Sacrifice His Civil Rights to Be a Civil Servant? 4 CAL. W.L. REv. 1 (1968). 
deleterious or adverse effect in the area of employment, ${ }^{85}$ impedes or interferes with the employee's job performance or the efficiency of the operation of which he is part, ${ }^{86}$ or has a bearing upon the employee's coinpetence or fitness. ${ }^{87}$

When a public employee seeks judicial redress for an infringement of his right to privacy by an employment decision, a formidable arsenal can be utilized to secure his claim: the requirement of a compelling state interest to validate privacy infrimgements, the requisite that the employer must implement the least restrictive of the regulatory alternatives, strict judicial scrutiny of the asserted justifications for the employer's infringement, and the apparent option of absolutely prohibiting the conditioning of public employment upon the surrender of one's personal privacy. Even the alternative balancing test as applied in Pickering would severely restrict the public employer's decisionmaking. Since the recent privacy decisions have introduced a judicial discretion sufficient to encompass almost any private conduct which an employer could deein "immoral," the power to alter substantially the traditional right of a public employer to hire and fire in accordance with his views of what private behavior constitutes "immorality."

\section{DifFicUlties IN Vindicating THE EMPLOYEE'S RighT to PrIVACY IN THE COURTS}

Despite the recently expanded constitutional protection of private interests and the stepped-up standards of judicial review, one must be cautious in assuming that these rights are readily enforceable and thus will have a significant effect upon employment practices. As has been emphasized, the characteristics of the right to privacy and of the standards of judicial review are such that judges have been given wide latitude in deciding individual cases. This fact can certainly work against as well as for the public employee. Not every judge will be eager to follow the temptation of Wade and create new constitutionally protected interests on the basis of public policy considerations. If the interest has not been specifically protected by a higher court's decision, there is little in the vaporous definitions of the recent right-to-

85. See, e.g., Acanfora v. Board of Educ., 359 F. Supp. 843, 853 (D. Md. 1973); Jarvella v. Board of Educ., 12 Ohio Misc. 288, 299, 233 N.E.2d 143, 145 (Ct. C.P. 1967).

86. See, e.g., Pickering v. Board of Educ., 391 U.S. 563, 569-70 (1968); Johnson v. Branch, 364 F.2d 177, 182 (4th Cir. 1966), cert. denied, 385 U.S. 1003 (1967).

87. See, e.g., Shelton v. Tucker, 364 U.S. 479, 488, 490 (1960).

88. See notes $34,39-54$ supra and accompanying text. 
privacy cases $^{89}$ to prevent a judge from finding the possibly offensive conduct to be outside the "penumbra" or not "implicit in the concept of ordered liberty." The standards of judicial review, with the exception of the absolutist "unconstitutional conditions" approach, have the same flexible quality. The "compelling state interest" doctrine, for example, can be expanded to cover apparent trivialities. ${ }^{90}$ The test of the least restrictive alternative can be passed as well as failed, for a court might easily uphold a dismissal on the grounds that no alternative would impinge less upon the area of protected privacy and still serve the state interest. Such a conclusion would find support in the principle, approved by the Supreme Court, that the state is not constitutionally bound to choose "ineffective means" im order to meet the requirement that the state "use to a proper end the means designed to impinge minimally upon fundamental rights."11

Moreover, several practical factors militate strongly against the likelihood that a wronged public employee will ever seek enforcement of his right to privacy in the courts. These problems are to a large extent identical to those which have arisen in the context of the first amendment rights of teachers:

[T] he costs of formal controversy are high and usually must be borne personally, the burden of proof-often exceedingly difficult to carryfalls upon the plaintiff-teacher, and the ordinary case may not reach judgment for inonths or even years after the plaintiff has separated from his job. In addition, the teacher must face the practical recognition that the extralegal hazards of such litigation are themselves quite great: to sue and to lose establishes a public record against oneself as a teacher, and inay further prejudice one's chances for einployment or advancement. To sue and to win will not permit one actually to resume teaching at the institution in inost imstances, and it will almost certainly spread upon the public record whatever evidence of the

89. See text accompanying notes $34,40-41$, 44 supra.

90. See note 51 supra.

91. Rosario v. Rockefeller, 410 U.S. $752,762 \mathrm{n.10}$ (1973), upholding, as a valid means to preserve the integrity of the electoral process, a New York election law requiring a voter to enroll in the party of his choice at least thirty days before the general election in order to maintain the voter's franchise for that party's next primary. The Court concluded that there were no means less restrictive of voting rights and still adequate to serve the state interest. Cf. Winters v. New York, 333 U.S. 507, 533 (1948) (dissenting opinion), where Justice Frankfurter explained:

Legislation must also avoid so tight a phrasing as to leave the area for evasion ampler than that which is condemned. How to escape, on the one hand, having a law rendered futile because no standard is afforded by which conduct is to be judged, and, on the other, a law so particularized as to defeat itself through the opportunities it affords for evasion, involves an exercise of judgment which is at the heart of the legislative process. 
plaintiff's shortcomings the defending institution can muster. . . . ${ }^{92}$

Because of the often sensitive and embarrassing nature of "immoral" conduct, the obstacles are even more formidable for an employee who feels that his dismissal was due to a superior's disapproval of his private life. A far bolder spirit is required of an employee who would enter the courtroom and "spread upon the public record" an account of his personal intimacies than is required of an employee who charges that he has been dismissed for criticizing the school administration ${ }^{93}$ or for taking part in a civil rights demonstration..$^{04}$

Further difficulties for the discharged employee will arise as employers become more aware of relevant constitutional law and simply disguise their motives. ${ }^{95}$ It is significant that the cases which have established the principles for the unconstitutional removal of public employees have featured the einployer's open admission that the dismissal was directly due to the exercise of a constitutional right. ${ }^{96}$ When the employer is silent as to his true motives, the employee who believes that his constitutionally protected private activity was the basis for his dismissal will face a threefold discouraging effect: (1) the difficulty of carrying the burden of proof will be greatly imcreased, as the employee will be obligated to find specific evidence linking his dismissal to the intimate activity;7 (2) an adequate investigation into the employer's real motives would often necessarily broaden the exposure given to the employee's personal intimacies, especially when the re-

92. Van Alstyne, The Constitutional Rights of Teachers and Professors, 1970 DUKe L.J. 841, 859-60. There is, of course, no very reliable means to document how many excluded employees are discouraged by the prospect of these difficulties from seeking vindication of their rights, but the author's remarks concerning this one class of employees are illuminating:

In view of the practical difficulties of litigation, however, it is not surprising that there have been vastly fewer such successful cases than, for instance, the number of cases whicl the American Association of University Professors' annual cascade of investigative reports have considered meritorious in point of fact. $I d$. at 859 .

93. See Board of Regents v. Roth, 408 U.S. 564 (1972); Pickering v. Board of Educ., 391 U.S. 563 (1968).

94. See Johnson v. Branch, 364 F.2d 177 (4th Cir. 1966), cert. denied, 385 U.S. 1003 (1967); cf. O'Neil, supra note 74, at 79: 'It is one thing to admit publicly that one is a Communist. . . . But it is quite another matter to advertise that one lhas been fired because he is or is suspected of being a liomosexual, an adulterer, or just an 'oddball.' "'

95. See Comment, supra note 57, at $1058-59$ n.31, 1062 n.47.

96. See, e.g., Pickering v. Board of Educ., 391 U.S. 563 (1968) (freedom of speech); Keyishian v. Board of Regents, 385 U.S. 589 (1967) (freedom of association); Shelton v. Tucker, 364 U.S. 479 (1960) (freedom of association); Slochower v. Board of Educ., 350 U.S. 551 (1956) (invocation of privilege against self-incrimination before senate subcommittee).

97. See Comment, supra note 57, at 1058-59 n.31. 
sponsible officials remain tight-lipped and evidence of the employer's motives must be gathered from the interrogation of third parties; and (3) the discharged employee must shoulder the psychological burden of initiating public discussion of his private life.

\section{Internal Procedures for Review: Their Availability AND FAIRNESS}

Because of the imposing difficulties which confront a discharged employee seeking to vindicate lis right to privacy in the courts, the importance of a fair procedure within the governmental or institutional framework is correspondingly enhanced. ${ }^{.8}$ An internal pretermination review procedure that reduces einbarrassing publicity and minimizes litigation costs, effort, and delay would naturally be more conducive to the airing of einployee grievances than the prospect of a lengthy courtroom spectacle.

Often, of course, a public employee can invoke applicable statutes which either explicitly require a pretermination hearing or may be plausibly read to do so.99 In such cases, even if the employer has refused to provide a hearing, the employee will be able to obtain a court order requiring statutory compliance without raising the issue of his private activity, though the discouraging factors of cost, time, and delay associated with litigation would remain. Even in the absence of statutory protection, a pretermimation hearing is constitutionally compelled in certain circumstances. Although the Supreme Court has consistently refused to formulate blanket rules as to when due process requires a pretermination hearing, several general principles with respect to pretermination learings are readily ascertainable. ${ }^{100}$ For exaunple, an em-

98. See Van Alstyne, supra note 92, at 860.

99. See, e.g., Greene v. McElroy, 360 U.S. 474 (1959), where an aeronautical engineer had lost his position with a defense manufacturer after the federal government revoked his security clearance. The opportunity for him to practice his chosen profession was thus effectively denied. He was not allowed to confront the anonymous accusers who had alleged various subversive-related activities. Finding that the employee could not be dismissed after such a hearing, the Court rested its decision upon a determination that the relevant statutes and Executive Orders did not authorize such summary procedure. But the bulk of the opinion deals with the subject of procedural due process:

Certain principles have remained relatively immutable in our jurisprudence.

One of these is that where governmental activity seriously injures an individual, and the reasonableness of the action depends on fact findings, the evidence used to prove the Government's case must be disclosed to the individual so that he has an opportunity to show that it is untrue. . . We have formalized these protections in the requirements of confrontation and cross examination. Id. at 496 .

100. See generally Note, Public Employees Right to a Pre-Termination Hearing Under the Due Process Clause, 48 IND. L.J. 127 (1972). 
ployee is guaranteed such a hearing whenever his dismissal would place a "badge of infamy" upon his reputation, such as occurs when termination brands an employee a drunkard or a traitor. ${ }^{101}$ An employee is also entitled to a hearing when his disinissal would have the effect of excluding him froin a whole profession rather than a specific job. ${ }^{102}$ These principles are clearly operative in dismissals for "immorality," especially when specific charges are leveled. If a discreet though unlucky adulterer or fetishist were to be dismissed by a public employer, the "badge of infamy" is patent; and it can be safely assumed that a termination under such an opprobrious label would significantly impair one's ability to find equivalent employment.

When no reasons at all are given for the dismissal, and thus the arguments based on a "badge of infamy" or on the effect upon future employment prospects are significantly weaker, an employee dismissed for private behavior will face imposing obstacles in establishing a right to a pretermination hearing. The argument has been made that dismissal from public employment in itself carries a substantial enough onus that the employee's reputation is imjured, his ability to obtain other employment is impaired, and that thus any public employee faced with dismissal should be constitutionally entitled to a pretermination hearing. ${ }^{103}$ A more elaborate theory reaching the same result has empliasized the pervasiveness of government im modern society and has concluded that public benefits, imcluding employment, should be treated as "new property" to which the requirements of due process would

101. Compare Board of Regents v. Roth, 408 U.S. 564, 573 (1972) (reversing grant of summary judgment for teacher dismissed from state university without a hearing, but also without the leveling of charges which would seriously damage his reputation) and Cafeteria Workers Local 473 v. McElroy, 367 U.S. 886, 898 (1961) (upholding dismissal of civilian cook at defense installation by summary government action which specified no particular faults-thus there was no "badge of disloyalty or infamy") with Wieman v. Updegraff, 344 U.S. 183, 191 (1952) (dismissal from public employment on disloyalty grounds); cf. Wisconsin v. Constantinou, 400 U.S. 433, 437 (1971) (invalidating state statute requiring the posting of notice, without prior hearing, in retail liquor outlets that sales or gifts of liquor to named individuals were forbidden); Joint Anti-Fascist Refugee Comm. v. McGrath, 341 U.S. 123, 139 (1951) (designation, without hearing, of organization as Communist held violative of procedural due process).

102. Compare Cafeteria Workers Local 473 v. McElroy, 367 U.S. 886, 898-99 (1961) (nothing to indicate that dismissal from civilian position at military installation affected employment opportunities elsewhere) with Greene v. McElroy, 360 U.S 474, 492 (1959) (right to follow chosen profession is liberty and property interest protected by due process) and Orr v. Trinter, 444 F.2d 128, 133 (6th Cir. 1971), cert. denied, 408 U.S. 943 (1972) (denial of license or opportunity to practice chosen profession requires hearing and opportunity to respond to charges).

103. See Comment, supra note 57, at 1065-67. 
necessarily attach. ${ }^{104}$ A constitutional entitlement to a pretermination hearing would provide all public employees with a forum where they could contest their dismissals with minimal effort, embarrassment, and cost. $^{105}$

The Supreme Court, however, has been unwilling to go so far. In Board of Regents $v$. Roth, ${ }^{106}$ the Court held that, in order to qualify for a pretermination hearing, the employee's interest must be encompassed within the fourteenth amendment's protection of "liberty" or "property."107 Employees protected by statute, contract, or implied ted):

104. Reich, The New Property, 73 YALE. L.J. 733, 783-84 (1964) (footnotes omit-

The grant, denial, revocation, and administration of all types of government largess should be subject to scrnpulous observance of fair procedures. Action should be open to hearing and contest, and based upon a record subject to judicial review. The denial of any form of privilege or benefit on the basis of undisclosed reasons should no longer be tolerated. Nor should the same person act as legislator, prosecutor, judge and jury, combining all the functions of government in such a way as to make fairness virtually impossible.

105. It would also obviate the necessity of establishing the right to a pretermination hearing on a case-by-case basis.

106. 408 U.S. 564 (1972) (nontenured state university teacher, hired for one year on a probationary basis, was informed without explanation that his contract would not be renewed).

107. Id. at 569. The district court in particular had given great emphasis to the "hardship" aspects of the case, Roth v. Board of Regents, 310 F. Supp. 972, 979 (W.D. Wis. 1970), and had balanced the interests of the teacher and the university administration. The Supreme Court held this analysis to be erroneous:

[A] weighing process has long been a part of any determination of the form of hearmg required in particular situations by procedural due process. But, to determine whether duc process requirements apply in the first place, we must look not to the "weight" but to the nature of the interest at stake. . . .

We must look to see if the interest is within the Fourteenth Amendment's protection of liberty and property. 408 U.S. at 570-71 (footnote omitted).

The slighting of "hardship" factors and the emphasis upon a liberty-or-property interest paralleled a development in the related field of welfare benefits and public action affecting one's personal possessions. Goldberg v. Kelly, 397 U.S. 254 (1970), lield that the termination of public assistance payments without opportunity for a pretermination evidentiary hearing violates due process. While emphasizing that the benefits were a statutory entitlement for eligible recipients, id. at 262, the Court accorded great weight to what can only be described as "hardship" arguments: "The extent to which procedural due process must be afforded the recipient is influenced by the extent to which he may be 'condemned to suffer grievious loss' . . . and depends upon whether the recipient's interest in avoiding that loss outweighs the governmental interest in summary adjudiciation." Id. at 263 (citation omitted). "[T]ermination of aid pending resolution of a controversy may deprive an eligible recipient of the very means by which to live while he waits." Id. at 264. Two years later, in Fuentes v. Shevin, 407 U.S. 67 (1972), the Supreme Court held that the summary seizure of goods under a writ of replevin without a prior hearing violates procedural due process. The Court's emphasis in Fuentes had shifted wholly to the "property" analysis. Goldberg was treated as "in the mainstream of past cases, having little or nothing to do with the absolute 'necessities' of life but establishing that due process requires an opportunity for a liearing before a deprivation of property takes effect." Id. at 88 (footnote omitted). 
promise hold such a property interest; but a nontenured teacher, for example, does not. ${ }^{108}$ The Court in Roth and in its companion case, Perry v. Sindermann, ${ }^{109}$ also made it clear that the employee's bald assertion that his disnissal was due to constitutionally protected conduct will not establish a right to a pretermination hearing. ${ }^{110}$ The effect of Roth's categorical hiberty-or-property interest requirement is that applicants and employees with valid privacy claims who carmot qualify for a pretermination hearing will continue to have no recourse except to the courts, a procedure which would activate all the discouraging factors detailed elsewhere in this Note. ${ }^{111}$ For such persons, the expanded judicial protection of the right to privacy will have created a right without a readily enforceable remedy.

Even as to those employees who can qualify, questions arise as to the effectiveness and fairness of any foreseeable pretermination procedure. It inust first be recognized that many of the factors which would discourage an employee from seeking redress in the courts would also apply to an internal review or administrative hearing. For example, a dismissed employee who does not wish to make his private sexual relations the focus of a courtrooin controversy will not necessarily be anxious to argue the matter before a panel of superiors or review board. Also, the latitude which the ill-defined constitutional standards have placed in the hands of the courts will be available to reviewing officers as well.

For those einployees who are not deterred by these obstacles,

108. Board of Regents v. Roth, 408 U.S. 564, $576-78$ (1972). The Roth opinion did reaffirm the principle that serious damage to personal reputation or a stigma affecting one's freedom to find alternative employment would necessitate heightened procedural protection. The Court designated such injuries as deprivations of "liberty." 408 U.S. at 572-75. See notes 101-02 supra. Although the Supreme Court found insufficient evidence of either injury in the Roth case, it should be noted that the district court concluded that the nonretention would seriously impede the teacher in his future academic career, 310 F. Supp. at 978-79.

109. 408 U.S. 592 (1972). In Perry a nontenured teacher had been employed as a junior college professor for four years under a series of one-year contracts, following six years elsewhere in the state college system. As in Roth, the teacher had publicly criticized the administration, and his contract was allowed to lapse. He charged that his dismissal was due to the criticisms that he had made and that the failure to provide a hearing violated due process. His complaint alleged further that there was a de facto tenure policy in effect at the college, evidenced by various "rules and understandings," including provisions in the college's official Faculty Guide. The Court held that, if such an implied agreement could be shown to be the practice at the particular institution, the teacher would have demonstrated a property interest sufficient to qualify for a hearing at the college. Id. at 599-603.

110. Id. at 599 n.5; Board of Regents v. Roth, 408 U.S. 564, 575 n.14 (1972).

111. See notes 89-96 supra and accompanying text. 
vindication of the right to privacy will depend upon the fairness of available internal procedures. The inost difficult obstacle to be overcome at this point will be the intransigence and intolerance of the reviewing officials themselves when they are confronted by an employee whose dismissal is pending for "immoral" conduct. In the absence of sweeping and unforeseeable changes in administrative procedure, it can be safely assumed that reviewing officers in the vast majority of cases will continue to be drawn frown within the employer agency or institution. ${ }^{112}$ This assumption raises serious doubts as to the fairness which a dismissed employee can expect before a tribunal so constituted. The reviewing officers, even if they took no part in the decision to dismiss, are likely to support their peers and approve of the reasons for dismissal, especially if the conduct is offensive to thein. The hearing could easily degenerate into an unwarranted but determinative inquiry as to "whether the employee has in fact grown a beard, written a hostile letter, or slept with his girlfriend. . .."113 All that would then be accomplished would be "to make a record for a reviewing court," ${ }^{\prime 14}$ and the einployee would have to face the multitude of difficulties which would have confronted him as a prospective litigant in the first place.

It can be seen, then, that procedural safeguards which fall short of mandating that the trier of fact be an impartial outsider are too likely to founder on the decision-maker's predetermined opinion. Solne means of third-party review seems to be the only procedure which would provide vimdication of privacy rights without resorting to the courts for litigation of the merits of the privacy claim. The Supreme Court has firmly established the principle that the degree of procedural protection required in a given case is determined by an ad hoc weighing of the competing individual and public interests. ${ }^{115}$ In the employment

112. Even the most extensive due process requirements laid down by the Court have assumed that the hearing will be conducted by a member of the agency or institution which issued the original decision. See, e.g., Goldberg v. Kelly, 397 U.S. 254, 271 (1970): "[P]rior involvement in some aspects of a case will not necessarily bar a welfare official from acting as a decision maker. He should not, however, have participated in making the determination under review." The commentators have likewise recognized the practical requirements of the situation: "Considerations of economy, as well as the advantages of having someone already familiar with the requirements of a given iob classification, dictate that someone who is closely associated with the dismissing agency serve as reviewer." Comment, supra note 57 , at 1079 n.121.

113. O'Neil, supra note 74 , at 111 .

114. Id.

115. See, e.g., Goldberg v. Kelly, 397 U.S. 254, 263 (1970), quoting Cafeteria Workers Local 473 v. McElroy, 367 U.S. 886, 895 (1961) ("consideration of what proce- 
context, this test balances the degree of hardship which a dismissal would impose upon the employee against the degree of inconvenience which a given procedure would impose upon the public employer. ${ }^{116}$ The courts are unlikely to abandon this test in favor of a blanket rule that third-party review is required in dismissals from public employment; for the courts have hesitated to do so even in those analogous cases involving utility cutoffs and the termination of welfare benefits where judges have appeared to be most sympathetic, ${ }^{117}$ perhaps because of the enormous expense which such an across-the-board requirement would occasion. Nor is the Supreme Court likely to carve out a special procedure for employees who allege that their dismissal was due to their engaging in a constitutionally protected activity, for such an exception would encourage frivolous and unwarranted claims. ${ }^{118}$

In all likelihood, employment decisions will continue to be judged on an ad hoc basis, a prospect requiring that an employee, if not clearly entitled to a pretermination hearing under Roth, first resort to the courts to obtain a degree of procedural protection greater than that which his employer has provided. Although the employee would not have to litigate fully his privacy claim at this stage, he would not only bear the expense of a court proceeding but would also be required to present inore than a bare allegation of a privacy infringement. ${ }^{119}$ Since the effectiveness and the fairness of any foreseeable, court-mandated pretermination procedure must be seriously questioned, ${ }^{120}$ the likelihood of the hearing's producing a result favorable to the employee is slight. The employee would then be forced to resort a second time to the courts for a hearing on the merits of his privacy claim. The burdens of this roundabout procedure make it improbable that the procedural protection provided by Roth will result in an effective al-

dures due process may require under any given set of circumstances must begin with a determination of the precise nature of the government function involved as well as of the private interest that has been affected by governmental action"); Hannah v. Larche, 363 U.S. 420,442 (1960).

116. Cafeteria Workers Local 473 v. McElroy, 367 U.S. 886, 895-96 (1961).

117. See note 112 supra. See Palmer v. Columbia Gas, Inc., 479 F.2d 153 (6th Cir. 1973) (hearing to determine validity of gas service termination may be conducted by employee in management position).

118. In its recent decisions, the Supreme Court has made it clear that merely alleging that one's dismissal was due to constitutionally protected activity will not entitle one to a pretermination hearing. See note 110 supra and accompanying text. There is no obvious reason why the principle would not apply equally to an employee who demands heightened procedural protection once the right to a hearing is established.

119. See note 110 supra and accompanying text.

120. See notes 112-18 supra and accompanying text. 
ternative for those employees who do not wish to seek judicial review in the first place.

\section{CONCLUSION}

The present dimensions of a public employer's right to condition employment upon compliance with moral codes are constitutionally uncertain, due to the ill-defined nature of the right to privacy and to extremely flexible and unpredictable standards of judicial review. However, it is now at least certain that the public employer's traditional prerogatives have been substantially diminished. Whether more than a few employees will actually invoke this expanded judicial protection is another matter entirely, for the litigation of necessarily sensitive issues poses obstacles even more formidable than the difficulties which face a public employee seeking redress for infringements of other rights. The importance of internal review is manifest. The Supreme Court, lowever, has for the present excluded whole classes of applicants and einployees from the right to a pretermination hearing; and there are reasons to doubt seriously that those employees who are entitled to administrative review will inake much headway against intolerant superiots.

Thus, notwithstanding the significant recent expansions of the public employee's right of privacy in the cases from Griswold to Wade $^{121}$ and the increasingly rigorous judicial review accorded public hiring decisions affecting that right, ${ }^{122}$ vindication of the public employee's privacy rights will depend primarily upon several factors beyond the control of the courts: (1) the extent to which the public employers themselves abandon the notion that they should control the private lives of their employees, whether this change of heart manifests itself in legislation or simply in a inore tolerant attitude on the part of supervisors througliout the various hierarchies of public employers; (2) the extent to which labor organizations of public employees extract concessions as to the authorized reasons for dismissal and the availability of arbitration procedures to guarantee a fair pretermination procedure; and (3) in the absence of such developments, the degree to which the employees themselves become bolder and more persistent in seeking vindication of their privacy rights in the courts.

121. See notes 15-54 supra and accompanying text.

122. See notes 55-88 supra and accompanying text. 